\title{
有機分子および酸素の気/固物理吸着平衡に 対する磁場の影響
}

\author{
宮本淳一松原良子 倉嶋 太 \\ 田崎貴之 尾関寿美男
}

千葉大学理学部化学科

J. Japan Inst. Metals, Vol. 61, No. 12 (1997), pp. 1300-1305

\section{Magnetic Effects on Physical Adsorption Equilibrium between Solids and Gases of Organic Molecules and Oxygen}

\author{
Junichi Miyamoto, Yoshiko Matsubara, Hutoshi Kurashima, \\ Taka Tazaki and Sumio Ozeki \\ Department of Chemistry, Faculty of Science, Chiba University, Chiba 263
}

\begin{abstract}
The magnetic field effects on gas-solid interactions were examined, using physical adsorption systems of methanol, $t$-butanol, benzene and $\mathrm{O}_{2}$ onto carbon black (NPC), activated carbon fiber (A10) and zeolite $5 \mathrm{~A}$ $(\mathrm{Z} 5 \mathrm{~A})$. With some previous results on the magnetic-field-induced adsorption and desorption of $\mathrm{H}_{2} \mathrm{O}$ and NO, a possibility of the magnetic control of gas/solid adsorption equilibrium was discussed. When a homogeneous steady magnetic field was applied to such gas/solid adsorption systems under equilibrium, amount of adsorption changes, being referred to magnetoadsorption (MA) and magnetodesorption (MD). The dependence of MAD on magnetic field intensity was classified into four types, depending on the kind of solids and adsorptives: MD(I), MA(II), MD-to-MA transition (III), and MA-to-MD transition (IV). Benzene/NPC, $\mathrm{O}_{2} / \mathrm{A} 10$ and $\mathrm{O}_{2} /$ Z5A systems were type II and a methanol/NPC system was type IV (which was first observed). To understand thermodynamically MAD, we must presume certain magnetic states in adsorbed phases different from its bulk phase, which should arise from interaction between an adsorptive and a solid and/or between adsorptives during the adsorption process. Thus, it is possible that adsorption equilibrium is controlled by an external magnetic field, designing magnetic interactions in the adsorption process.
\end{abstract}

(Received June 13, 1997)

Keywords: adsorption, magnetic field, magnetic effect, magnetoadsorption, magnetodesorption activated carbon fibers, zeolite $5 \mathrm{~A}$, benzene, methanol, water, $\mathrm{NO}, \mathrm{O}_{2}$

\section{I 。緒言}

磁場のエネルギーは熱エネルギーに比べても遥かに小さい から，通常手にはいる磁場によって化学平衡を移動させるの はそれ活ど容易ではない，物理吸着の吸着エネルギーは 10 $\mathrm{kJ} / \mathrm{mol}$ のオーダーであるから，1 $\mathrm{T}$ の磁場の中で常磁性の 有機ラジカルの電子スピンのゼーマン分裂により変化するェ ネルギー $(0.01 \mathrm{~kJ} / \mathrm{mol})$ や反磁性物質の歹つ磁気エネルギー $(10 \mathrm{~mJ} / \mathrm{mol})$ よりも遥かに大きい。室温での熱エネルギー $(2.5 \mathrm{~kJ} / \mathrm{mol})$ 乙比べても千分の 1 以下であり，実験的には， 磁気エネルギーを摂動として系の変化を検出することは難し W.

固体表面に物理吸着した分子の吸着状態は吸着ポテンシャ ルとともに変わる.固体表面と直接相互作用する第 1 層内 の吸着分子は，多分子吸着層中の分子之は区別され，また， 細孔中の吸着分子とる区別される。この上5な固体表面と分
子との相互作用への外部磁場効果については，上述のような 事情からこれまでは活とんど研究されてこなかった。われわ れは， $\mathrm{H}_{2} \mathrm{O}$ 分子や NO 分子が磁性や表面構造などの異なる いろいろな固体に吸着する際に静磁場が及ぼす影響について 調へ、これらの分子が磁気吸・脱着することを見い出し た(1)ー(3). しかし，これまでに調べた分子は反磁性と常磁性 について各 1 種に過ぎず，また，NOの結果(303 K) は化学 吸着的傾向も強く, この現象の普遍珄や傾向を見極めるには 甚だ不十分である. 本論文では，反磁性の有機蒸気や常磁性 の酸素の物理吸着への磁場効果を調ベこれまでに得られた $\mathrm{H}_{2} \mathrm{O}$ 円O の物理吸着への磁場効果の結果と合わせ, 気/固 物理吸着平衡の磁場制御汸洘察した。

\section{II. 実験}

吸着量の測定は, Fig. 1 飞示すバラトロン理力センサー (MKS 社製，タイプ122）を使った容量法吸着量測定装置を 


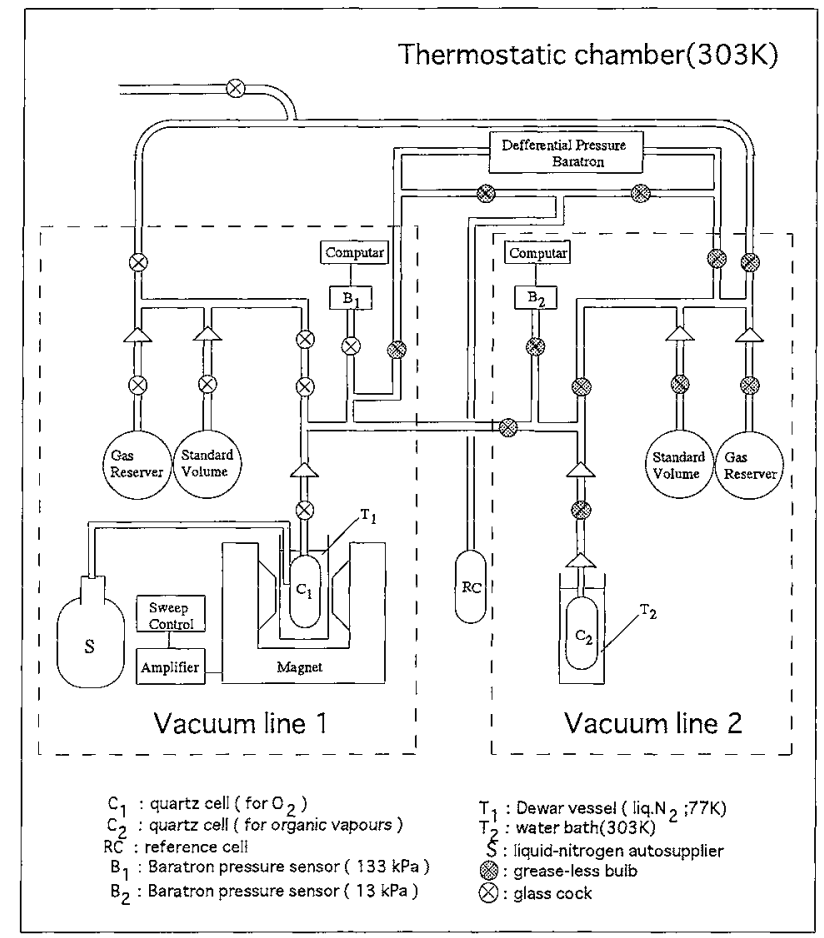

Fig. 1 Adsorption apparatus for magnetic effect.

用いた。吸着系を空気恒温槽に収め, $303 \pm 0.5 \mathrm{~K}$ に保った。 有機蒸気の吸着実験は、グリースレス真空ライン部 2 を用 い, $303 \pm 0.05 \mathrm{~K}$ の水恒温槽中で, 酸素吸着実験は真空ライ ン部 1 を用いて， $77 \mathrm{~K}$ の液体窒素ステンレス製デュワー瓶 中で行った，液体窒素の液面レベルを保つために，液体窒素 自動供給装置を自作し, 温度ゆらざによる囘力变化を抑克る よらにした。

吸着用矩形石英七儿を浱硝酸, 脱イオン水で洗浄, 乾燥さ せ, 予め $383 \mathrm{~K} て ゙ 12 \mathrm{~h}$ 以上予備乾燥した吸着媒をセル《詰 めた．セルを真空ラインに取り付忷，ロータリーポンプと油 拡散ポンプで十分に真空引きし, その後, 真空加熱処理 (1 $\mathrm{mPa}, 383 \sim 623 \mathrm{~K}, 2 \sim 5 \mathrm{~h})$ に上り前処理を行った. 吸着質導 入後, 压力が一定 $(p)$ Kなり吸着平衡になったことを確か め, 磁場を印加した. 压力が変化し, 数分で一定あるいは最 大変化値 $(p+\Delta p)$ 亿達したのち磁場を除去し, その可逆性を みた. 圧力の追跡恃圧力センサーからの出力電压を $\mathrm{A} / \mathrm{D}$ 変 換ボード(マイクロサイェンス社 DAS-1298XPC)を介してコ ンピュター(NEC PC-9800)に取り込んだ. 分解能は $5 \mathrm{mV}$ でめった。

磁場印加は電磁石(玉川製作所製, TM-YSV8110C$182 \mathrm{C}$; 磁極間距離 $18 \mathrm{~mm}$ ) で行い, 磁場强度は, 可变直流 定電压・定電流電源 (菊水電子工業製, PAD 35-20L)をスウ ィープコントロール装置(玉川製作所製)によって制御して, 励磁拉よび消磁時間，保持時間などを任意沉設定した。

水は蓔留水を脱イオンし, さらにアルカリ性過マンガン酸 カリウム水溶液から再蒸留し, さらに真空中で 3 度蒸留し
た. ベンゼンとメタノールおよびたブタノールは, 溶存酸素 の影響を取り除くため， 3 度凍結脱気した。カーボンブラッ クは三菱化成 32 (此表面積 $a_{\mathrm{s}}=69 \mathrm{~m}^{2} / \mathrm{g}$; 無孔性)，ピッチ 系活性炭素䋐維は大阪ガス $\mathrm{A} 10\left(a_{\mathrm{s}}=1230 \mathrm{~m}^{2} / \mathrm{g}\right.$; 均一多孔性 (細孔径0.7括よび $1.0 \mathrm{~nm}$ ))，ゼオライト $5 \mathrm{~A}\left(a_{\mathrm{s}}=400 \mathrm{~m}^{2} /\right.$ $\mathrm{g}$; 均一多孔性(紐孔径 $0.5 \mathrm{~nm}$ ) ) は和光純薬製を用いた。

\section{III. 結果}

\section{1. 有機蒸気の磁気吸着}

$303 \mathrm{~K}$ でカーボンブラック上ルメタノールを $6.8 \mathrm{kPa}($ 相 対圧 $p / p_{0}=0.31$ ( $p_{0}$ : 飽和蒸気圧)；全吸着量 $39.7 \mathrm{mg} / \mathrm{g}$ ) 尊 入し，吸着平衡に達したのち，0.1 T から $1.2 \mathrm{~T}$ まで順次磁 場を印加した. Fig. 2 亿みられるように，ONで示された磁 場印加と同時に圧力が変化し, 数分以内で活涪一定に達し, 磁場除去(OFF) に上って汪湾可逆的に圧力は回復した。 0.6 $\mathrm{T}$ 以下で隹磁場に上って压力は減少, すなわら磁気吸着し, $0.96 \mathrm{~T}$ 以上では磁場によって压力は増加, すなわち磁気脱 着した. 磁気吸着加ら磁気脱着に変わる磁場強度 (䠦界磁場 $H_{\mathrm{c}}$ ) 付近の $0.76 \mathrm{~T}$ での磁場応答の時間依存性は特徵的であ る.

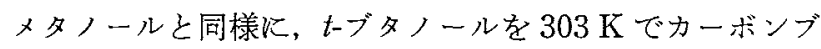
ラック上に $1.0 \mathrm{kPa}\left(p / p_{0}=0.30\right)$ 導入して磁場を印加したと ころ，1.2T 以下のすべての磁場強度で磁気吸着したが，そ の応答は小さく $(\Delta p<-7 \mathrm{~Pa})$, また, 不可逆的に, すなわ ち化学的饮吸着した。

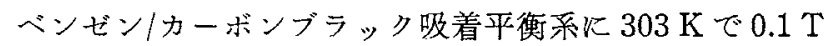
から $1.2 \mathrm{~T}$ の磁場を繰り返し印加した. Fig. 3 Kは、ベン ゼン化力が $5.5 \mathrm{kPa}\left(p / p_{0}=0.34\right)$ での一連の磁場印加実験の らち0.6 Tおよび $1 \mathrm{~T}$ の磁場を印加したときの例を示した。

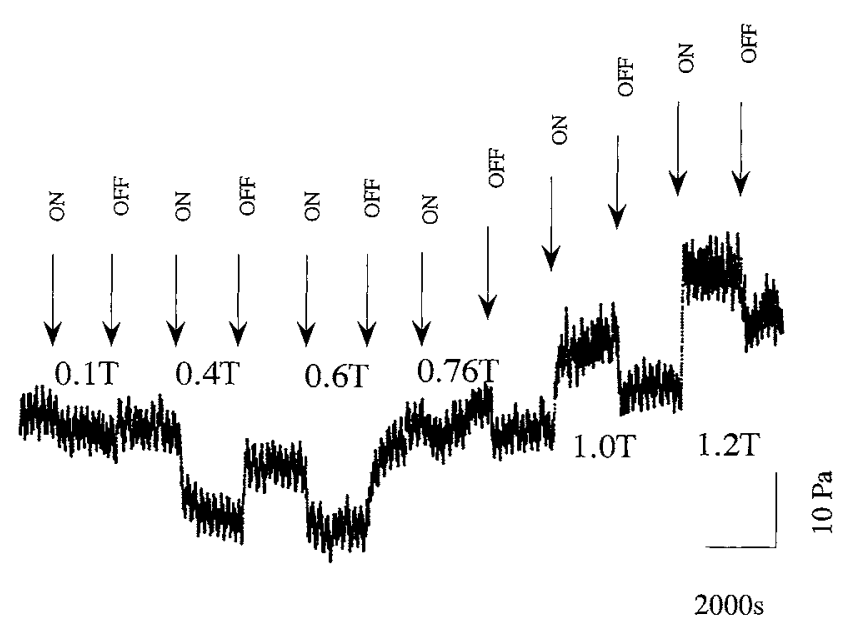

Fig. 2 Example of time course of methanol pressure with the application of various steady magnetic fields to carbon black/ methanol adsorption systems at $303 \mathrm{~K}$ and $6.8 \mathrm{kPa}$. Arrows: $O N$, application of a magnetic field; OFF, removal of a magnetic field. 

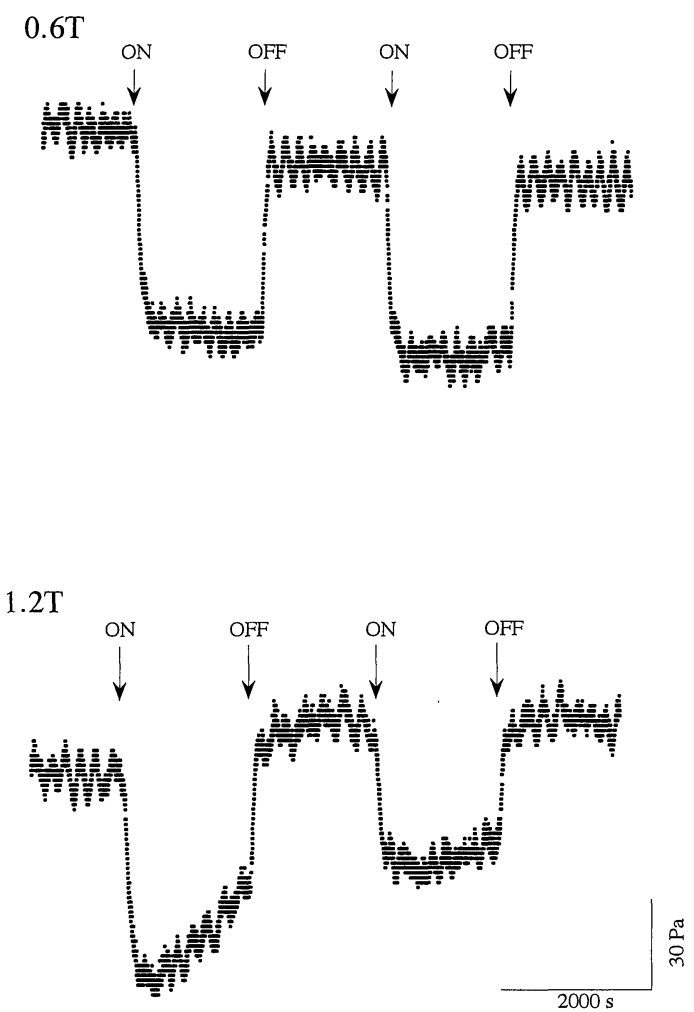

Fig. 3 Example of time course of benzene pressure with the application of steady magnetic fields to carbon black/benzene adsorption systems at $303 \mathrm{~K}$ and $5.5 \mathrm{kPa}$ : upper, $6.0 \mathrm{~T}$; lower, 1.2 T. Arrows: ON, application of a magnetic field; OFF, removal of a magnetic field.

再現性良く，注济可逆的に磁場応答しているのがわかる。べ ンゼンは, $t$-ブタノールと同様に実験した磁場領域では, 磁

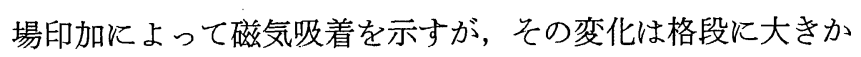
った(例光ば， $0.76 \mathrm{~T} て ゙ p / p_{0}=0.5$ のとき， $\Delta p \sim-93 \mathrm{~Pa}$ め るいは $\Delta p \mid p \sim-0.017)$.

Fig. 4 にメタノールとベンゼンの磁気吸・脱着量 $(\Delta p)$ の 磁場強度依存性を示した. いずれる，0.1 Tでは磁場応答は

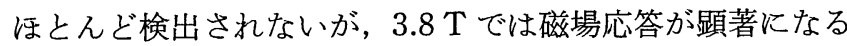
ことがわかる.

ここで試した有機蒸気の磁場応答は，tブタノールはもち ろんであるが,メタノールやベンゼンでさ光繰り返し実験に よって（日を执いた場合あるいは再度前処理を行った場合で も) 磁場応答が小さくなるか，みられなくなる場合があり， 吸着種あるいはカーボンブラックが不可逆的に变化したと思 われる。

\section{2. 酸素の磁気吸着}

活性炭素繊維 $\mathrm{A} 10$ やゼオライト $5 \mathrm{~A}$ 亿 $77 \mathrm{~K}$ で酸素を物 理吸着させたあと，1 T の磁場を印加した．Fig. 5 の例のよ うに, いずれの場合も圧力は可逆的に減少し, 磁気吸着を示 した. 図の圧力の変動はデュワー内の液面レベルの変化によ る.また，この図は，酸素のみの系でも磁場によってわずか
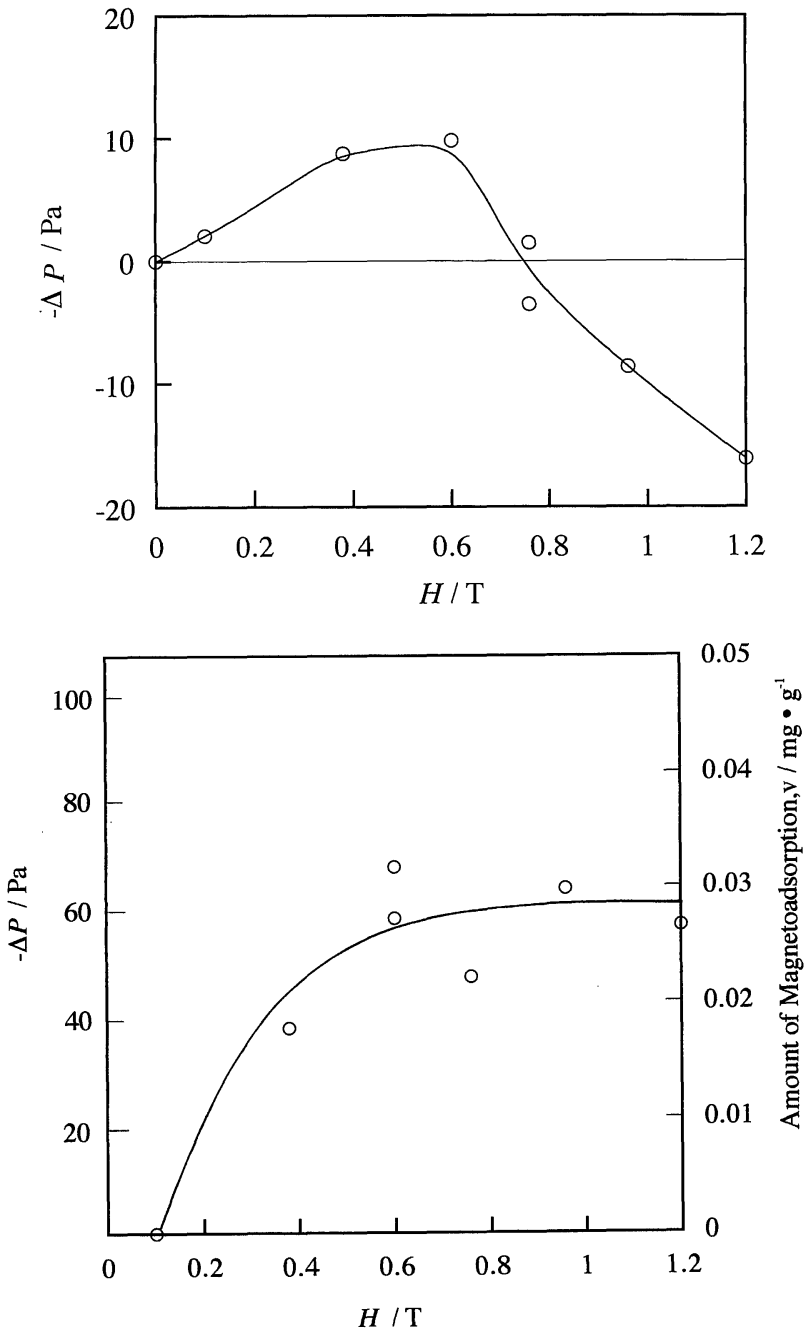

Fig. 4 Magnetoadsorption and magnetodesorption $(-\Delta p)$ of methanol and benzene onto carbon black at $303 \mathrm{~K}$ as a function of the steady magnetic-field intensity $(H)$ : upper, methanol; lower, benzene.

に圧力減少がみられたので，この減少分 $(p=13 \mathrm{kPa}$ のとき $1.3 \mathrm{~Pa}$ 以下)を補正してある. A10では, 数 $100 \mathrm{~Pa}$ 以下の 低圧で磁気吸着がみられたが，数 $\mathrm{kPa}$ 以上になると，圧力 ゆらぎもあって, 明確な結論は得られなかった。一方, ゼオ ライト $5 \mathrm{~A}$ では $p / p_{0}=0.7$ 高圧でも磁気吸着が検出された.

\section{N. 考察}

Table 1 亿種々の吸着媒/吸着質系に括ける磁場応答を磁 場強度依存性によって分類した．吸着量めるいは压力変化 $(\Delta p)$ の磁場強度依存性はこれまでに見つかっていた 3 種 類(2) に加えて, 今回のメタノールの場合を加光た 4 種類に 便宜的に分けた(Fig. 6).すなわち, 調べた全磁場強度域で 磁気脱着するもの(タイプI), 磁気吸着するもの(タイプII), 磁気脱着/吸着転移するもの (タイプIII) 打よび磁気吸着/脱着 転移するもの (タイプN)である. 水の磁気吸着の結果からタ イプIIIが般的であると推察したが, 今回, メタノール। 


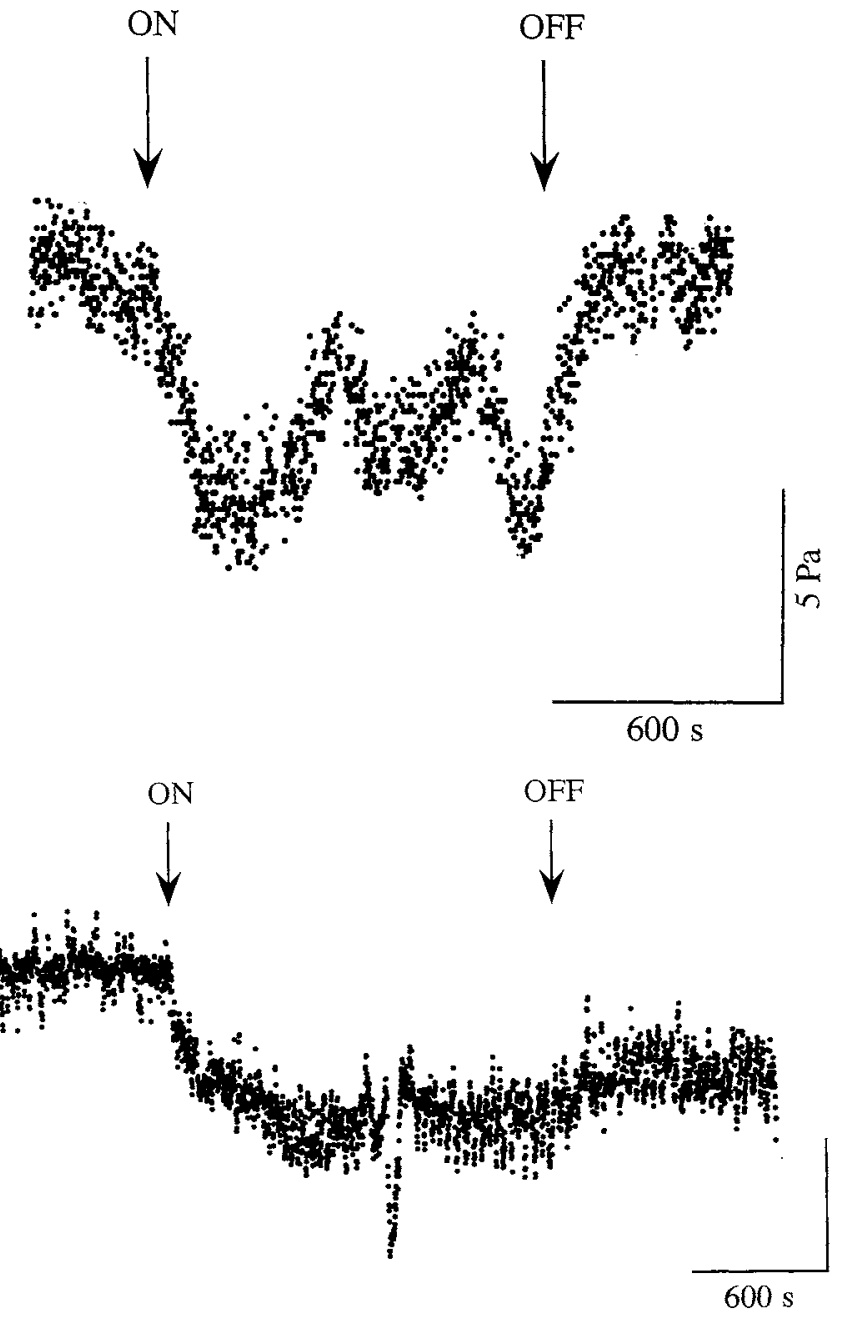

Fig. 5 Examples of time course of $\mathrm{O}_{2}$ pressure with the application of the steady magnetic field of $1 \mathrm{~T}$ to solid $/ \mathrm{O}_{2}$ adsorption systems at $77 \mathrm{~K}$ : upper, A10 (250 Pa); lower, zeolite $5 \mathrm{~A}(19 \mathrm{kPa})$. Arrows: $\mathrm{ON}$, application of a magnetic field; OFF, removal of a magnetic field.

NPC 系でタイプNの磁場依存性が見い出されたので，タイ プ正とタイプ $\mathrm{N}$ と大別する汇らが適当だと思われる。

このような磁気吸・脱着現象は熱力学的には次のように考 えられる. 温度 $T \mathrm{~K}$ で吸着平衡にある気体/固体系 $(p: H=0$ での平衡王)に磁場 $H$ をかけたときの磁気吸着に伴ら王力変 化が $\Delta p$, 磁場 $H$ のあとで 1 モルの分子が吸着するときの磁

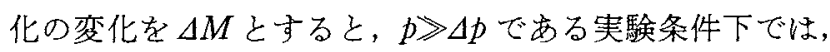
$\Delta p$ は

$$
\Delta p / p=-\Delta M H / R T
$$

と近似される。吸着相がいくつかの磁気相から成るときは， 式(1)の右辺は各相の寄与の総和となる.

式(1)によれば， $H$ と $T$ とが一定のもとで $\Delta p$ は $p$ 比 例し，その比例定数はー $A M H / R T$ で岁る。また， $\Delta p$ は $\Delta M$ あるいは磁化率の変化 $\Delta \chi$ の正負抏よび $H$ 依存性によ っているいるな磁場強度依存性を示す。すなら, 吸着によ
Table 1 Classification of magnetic field dependence of magnetoadsorption and magnetodesorption in various gas/solid systems.

\begin{tabular}{|c|c|c|c|c|c|c|c|}
\hline \multirow{2}{*}{ Type } & \multirow{2}{*}{ Pattern } & \multicolumn{6}{|c|}{ Adsorbates } \\
\hline & & $\mathrm{H}_{2} \mathrm{O}$ & $\mathrm{MtOH}$ & $t-\mathrm{BuOH}$ & benzene & No & $\mathrm{O}_{2}$ \\
\hline I & MD & $\begin{array}{l}\alpha-\mathrm{Fe}_{2} \mathrm{O}_{3} \\
\gamma-\mathrm{Fe}_{2} \mathrm{O}_{3} \\
2 \mathrm{nO} \\
\text { DNA }\end{array}$ & & & & $\left\{\begin{array}{l}\alpha-\mathrm{FeOOH} \\
\beta-\mathrm{FeOOH} \\
\gamma-\mathrm{FeOOH} \\
\delta-\mathrm{FeOOH}\end{array}\right.$ & \\
\hline II & MA & $\begin{array}{l}\mathrm{TiO}_{2} \\
\mathrm{Fe}_{3} \mathrm{O}_{4}\end{array}$ & & NPC & NPC & $\begin{array}{l}\mathrm{NPC} \\
\mathrm{A} 10 \\
\mathrm{AC} \\
\alpha-\mathrm{Fe}_{2} \mathrm{O}_{3} \\
\gamma-\mathrm{Fe}_{2} \mathrm{O}_{3} \\
\mathrm{NiO}\end{array}$ & $\begin{array}{l}\mathrm{A} 10 \\
\text { Z5A }\end{array}$ \\
\hline III & MD/MA & $\begin{array}{l}\mathrm{NPC} \\
\mathrm{AlO} \\
\mathrm{ZSA} \\
\mathrm{SiO}_{2} \\
\text { crysotile asbestos } \\
\text { montmorillonite } \\
\alpha-\mathrm{FeOOH} \\
\gamma-\mathrm{FeOOH}\end{array}$ & & & & & \\
\hline IV & $\mathrm{MA} / \mathrm{MD}$ & & NPC & & & & \\
\hline
\end{tabular}

MD: magnetodesorption, $\mathrm{MA}$ : magnetoadsorption, $\mathrm{MD} / \mathrm{MA}$ : transition of $\mathrm{MD}$ to MA, MA/MD: transition of MA to MD, $\mathrm{AC}$ : charcoal, molecular sieve carbon, celulose-, polyacryloamide-, and pitch-based activated carbon fibers

って系の磁化が減少するとき， $\Delta p>0$ (酳気脱着; 吸着量の 減少)，吸着相が気相よりもより常磁性的であるならば， $\Delta p<0$ (磁気吸着)でありらる. $\Delta \chi に H$ 依存性がなければ $\Delta p$ は $H^{2}$ に依存するはずであるが，実際にはFig.6 6 明ら かなよらに、系によって異なる $H$ 依存性を示した。したが って， $\Delta \chi$ 自身が $H$ の関数でなければならない. SQUID マ グネトメーターによって串測したところ, シリカやチタニア では，吸着した水のみかけの磁化率 $\chi_{\mathrm{app}}(=\{$ (水を吸着した 固体の磁化 $)-($ 固体の磁化 $)\} / H) ，$ したがって， $\Delta \chi\left(=\chi_{\text {app }}\right.$ 一 $\chi_{\mathrm{b}}, \chi_{\mathrm{b}}$; バルク蒸気の磁化率) $Ｈ$ 依存性は磁気吸着量の それと傾向は一致し，吸着水の磁化が磁気吸着に密接に関俰 していることを示唆した(2). 式(1)によれば，一般に吸着 相がバルクよりも数オーダー大きい磁化率を西つ成分を含む ならばここで観測された実測值 $(\Delta p)$ を説明することがで きる。

反磁性の水のカーボンブラックやA10への磁気吸・脱着 は, 種々の磁場強度 $(0.1 \sim 1 \mathrm{~T})$ のもとで $\Delta p$ は $p$ に比例し, 式( 1 ) と一致した ${ }^{(2)} . A 10 て ゙ は ， \Delta p と p$ (すなわ主吸着量) との間に性原点を通る直線が少なくとも 3 本みられ, 細孔 烽 $0.7 \mathrm{~nm}, 1.0 \mathrm{~nm}$ おびそれ以上のマイクロポアー $\mathrm{nm})$ 中の吸着水の磁場応答に対応していることがわかった. クリソタイルアスベストの円筒状メソポアー(直圣 $7.0 \mathrm{~nm}$ ) に毛管凝縮した水の磁場応答は各分子層吸着水のそれより小 さくなった，細孔径が大きくなるにつれて磁気応答は小さく なり，バルク水は磁気応答しないと思われる。 これらは，気 相から吸着相への分子の移行化伴ら磁化の变化 $\Delta M$ が吸着 相の磁気状態に依存していることを示唆している， $\Delta p$ の吸 

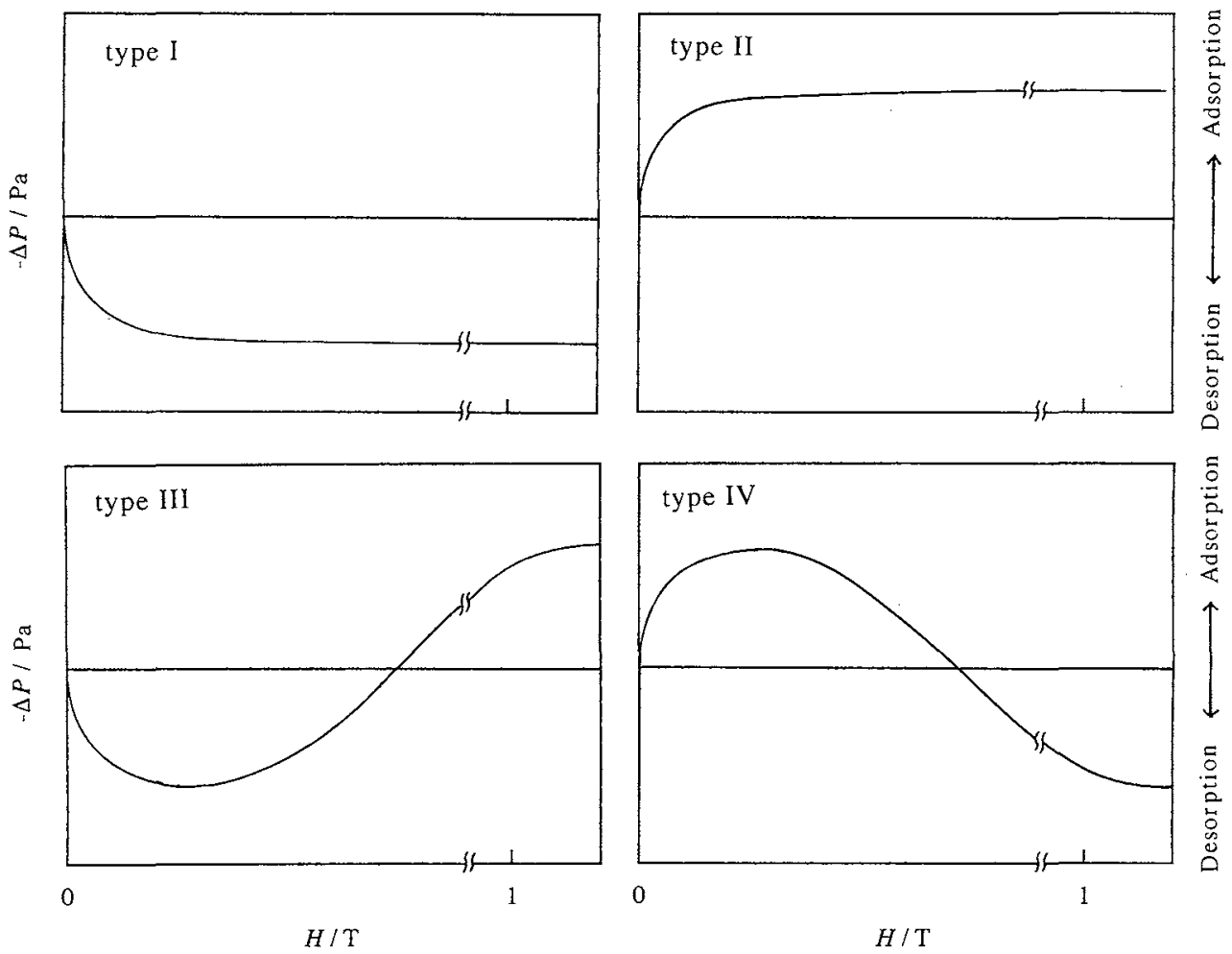

Fig. 6 Schematic patterns for magnetic field dependence of magnetoadsorption and magnetodesorption.

着量(吸着相の厚さ)あるいは細孔径依存性は，固体表面上お よび細孔中の吸着ドメイン(クラスター)のサイズとの相関も 示唆する。微細孔中への NOの磁気物理吸着(磁気マイクロ ポアーフィリング)は，細孔径が 0.5 およ゙ $1.0 \mathrm{~nm}$ のときに のみ顕著で, NO あるいはNO ダイマー(分子径 : $0.5 \times 0.41$ $\left.\times 0.30 \mathrm{~nm}^{3}\right)$ の単分子層和よび 2 分子層に相当する細孔の大 きさにフィットしたドメインを形成することの重要性を示し た(1).マイクロポアー中のNOは凝縮相を形成し，大部分 がNOダイマーとして存在していると考兄られているが(4)， NO の磁気マイクロポアーフィリングを反磁性のNOダイマ 一の生成に帰するには式(1)の観点からは無理がある。む しろNOよりもさらに常磁性的な吸着種を想定せざるを得 ない.

有機蒸気の実験は相対王 0.3 付近で行ったため，無孔性の カーボンブラックの外表面の多分子吸着層 (<2 層)が磁場応 答しているはずである。メタノールは，水と同様カーボンブ ラック上の官能基 $(\mathrm{OH}$ 基など)のまわりにクラスター状に吸 着しらるが，カーボンブラック上の水(タイプIII ; $H_{\mathrm{c}} \sim 0.8$ T) とは全く逆に $H_{\mathrm{c}}(\sim 0.8 \mathrm{~T})$ 以下で磁気吸着し, 高磁場側 で磁気脱着に転ずるタイプ Nに分類された。メタノールは水 の $\mathrm{H}$ を $\mathrm{CH}_{3}$ に置换しただけであるが，磁気応答に関しては 驚くべき違いが見い出された，おそらく，単分子吸着したメ タノールは低温でカーボンブラック (NPC)上でる，グラフ フイト上と同様に，リボン状に向か心合う分子間で水素結合 の一次元鎖を形成し ${ }^{(5)}$ ，水の二次元水素結合ネットワークと
異なる構造異方性(叔よび磁気異方性)を持つと思われる。こ のことが， NPC/×タノ一ル系が上述のシリカ/水系(タイプ III)の $\chi_{\text {app }}$ とは逆の $H$ 依存性をもつ一つの原因となっている かもしれない。これらを明らか炕するためには，実験的には 極めて難しいが，吸着層の構造と磁化を決定していく必要が ある。

ベンゼンは $1.2 \mathrm{~T}$ までの磁場印加によって大きな磁気吸着 を示した，反磁性分子の磁気吸着を，常磁性的吸着種の生成 によらないで熱力学的に説明する可能性の一つは，吸着分子 の磁場配向に上る吸着密度の増加に帰するものである．1つ 1つの反磁性分子では熱的に擾乱を受ける磁気異方性配向 が，ドメイン内の分子が共同的にふる李らことによって可能 になる配向性反磁性である。これは，Melvilleらによって超 反磁性と呼ばれたが(6)，このような例は液晶分子の磁場配列 に広くみられる(7). ベンゼン分子の磁気異方性は大きく $\left(\Delta \chi=5.4 \times 10^{-11} \mathrm{~m}^{3} / \mathrm{mol}\right)$ ，その磁気異方性エネルギーが $1 \mathrm{~T}$ で熱エネルギーに匹敵するには $10^{7}$ 分子から成るドメイ ンが形成されればよく，このときドメイン内のベンゼン分子 は磁場に平行に配向する．分子形状の異方性が大きなべンゼ ンは分子面をカーボンブラック表面に水平にして吸着してい るので，ベンゼン分子が磁場によって表面に垂直に（磁場に 平行に)配向すれば吸着密度が増加し(すなわら，ドメインが 成長し), 磁気吸着が起こる。このよ5に, 磁気異方性ェネ ルギーによって吸着分子の配向を变えるには，吸着媒/吸着 質相互作用は小さい方が良い。ベンゼン/NPC系はこの点で 
も大きく磁場応答しやすい.

吸着ドメイン内の共同的磁場配向性は, 拈とらく山岸ら ${ }^{(8)}$ による反磁性 Curie 則(反磁性磁化率の $1 / T$ 依存性 ; 又かけ の常磁性) と源を一にするものと思われ, この法則はべンゼ ンをはじめとする反磁性の小さな芳香族分子で広く確かめら れているが, われわれは, シリカ上の吸着水でも(磁気吸着 を示した $1 \mathrm{~T}$ で測定したところ) $\chi_{\mathrm{app}}$ の $1 / T$ 依存性を見い出 した(2).

ゼオライト $5 \mathrm{~A}$ /酸素系に $77 \mathrm{~K} て ゙ 1 \mathrm{~T}$ の磁場を印加する と, 酸素は磁気(物理)吸着した.この場合のように, 13 $\mathrm{kPa}$ 以上の酸素圧では, 酸素のみ(ゼオライト $5 \mathrm{~A}$ を含まな い系)でも圧力がわずかに減少した $(<1.3 \mathrm{~Pa})$ ので, ゼオラ イト $5 \mathrm{~A}$ の䨌囲気の酸素圧は上昇しているはずであるから, 圧力効果による間接的吸着促進とも考兄られる. しかし, A10でみられたように，250 Pa といった低酸素圧でさえ観 測される大さな磁気吸着は, 吸着媒付近の圧力効果による 間接的磁場効果では理解できない.

$\mathrm{A} 10$ に吸着した酸素は，ここでの実験条件 $(77 \mathrm{~K}, 250 \mathrm{~Pa})$ では, 二次元気体 (常磁性)/クラスター(ランダム磁性)混合 系であるとの報告があり (9), 大部分の吸着酸素は非磁性であ る. したがって, 常磁性酸素気体の磁化は吸着に伴って減少 することになり，この場合磁気吸着には至らないことになる.

一方, ゼオライト $5 \mathrm{~A}$ に吸着した酸素は, $77 \mathrm{~K}, 13 \mathrm{kPa}$ の条件では酸素ダイマー(直線状 $\mathrm{O}_{4}$ )を形成し, $\mathrm{Ca}^{2+}$ からの 静電場が大きい汪どシングレット(反磁性)が安定化されると の報告がある(10). 吸着量が多い場合には静電場の寄与が小 さくなり，トリプレット/シングレット $(\mathrm{T} / \mathrm{S})$ のエネルギー 差 $\Delta_{\mathrm{e}}$ は小さくなる. このとき, 磁場によるゼーマン分裂が $\Delta_{\mathrm{e}}$ 程度であれば $\mathrm{T}$ 状態(常磁性)をとることが可能になり, 磁気吸着が起こりらる.A10系でのクラスターも酸素ダイ マーを含めば，磁気吸着することになる．また，常磁性の $\mathrm{NO}$ も 10 上で $\mathrm{NO}$ ダイマー $\left(\mathrm{cis}-(\mathrm{NO})_{2}\right)$ を形成すると言わ れているので(4), 酸素と同様に磁気吸着が可能である.

\section{V. 結 論}

熱力学的考察は, 吸着に伴ら分子の磁気状態の変化を通し て静磁場中での磁場効果に定性的説明を与えるが, 観測され る圧力変化を定量的に説明するには, 極めて大きな磁気モー メントの変化を想定しなければならないなど, 磁気吸・脱着 現象のメカニズムを理解するには至っていない。 また, 各吸 着系に特有な問題を含み, 各論的傾向は否めない。たとえ ば, ここでは無視したが, 固体表面固有のスピンと吸着分子 との相互作用やそれへの磁場効果も拈そらく重要な要因であ ると思われるが, 分子/固体の組合せで異なり, 統一的に理 解することは現時点では極めて難しい。
磁気吸・脱着現象の $H$ 依存性がラジカルペアー反応への 磁場効果(11) や水素のオルト/パラ変換への磁気触媒効果 ${ }^{(12)}$ と類似していることから, これを量子力学的観点から見直す ことは自然である. $(\mathrm{NO})_{2}$ 分子上の 2 つの相互作用の弱い (局在化する傾向の強い) 不対電子(13)や $\mathrm{O}_{4}$ の $\mathrm{T}$ 状態はラシ カル対のようにらるまう可能性があり, このとき, 外部磁場 は電子スピンの $\mathrm{S} / \mathrm{T}$ 変換をと扎して吸着に影響することは ありらることである。また，水分子が固体表面に酸素原子で 吸着するとき，水分子は実際上 1 つの回転の自由度しか残 らず， $\mathrm{H}_{2}$ の回転状態に類似することになり，水素核スピン の磁気触媒 $\mathrm{S} / \mathrm{T}$ 変換が期待できる ${ }^{(2)}$.

このように, 種々の問題はあるものの反磁性有機分子ある いは物理吸着分子の磁気吸・脱着は現象論的には明らかであ り，比較的小さな磁場によって界面での吸着や反応(触媒)を 制御する可能性が示された。

\section{文献}

(1) S. Ozeki and H. Uchiyama: J. Phys. Chem., 92(1988), 6485; H. Uchiyama, S. Ozeki and K. Kaneko: Chem. Phys. Lett., 166(1990), 531; S. Ozeki, H. Uchiyama and K. Kaneko: J. Phys. Chem., 95 (1991), 7805; H. Uchiyama, K. Kaneko and S. Ozeki: Langmuir, 8(1992), 624; S. Ozeki, H. Uchiyama and K. Kaneko: J. Colloid Interface Sci., 154(1992), 303.

(2) S. Ozeki, C. Wakai and S. Ono: J. Phys. Chem., 95(1991), 10558; S. Ozeki, J. Miyamoto and T. Watanabe: Langmuir, 12(1996), 2115; S. Ozeki, J. Miyamoto, S. Ono, C. Wakai, S. Ono and T. Watanabe: J. Phys. Chem., 100(1996), 4205.

（3）尾関寿美男：分子磁性，伊藤公一編，学会出版，（1996）, 366; S. Ozeki, H. Uchiyama, S. Ono, C. Wakai, J. Miyamoto and K. Kaneko: Characterization of Porous Solids III, Ed. by J. Rouquerol, R. Reinoso, K. S. W. Sing and K. K. Unger, Elsevier, London, 87(1994), 383.

(4) K. Kaneko, N. Fukuzaki and S. Ozeki: J. Chem. Phys., 87 (1987), 776; K. Kaneko, N. Fukuzaki, K. Kakei, T. Suzuki and S. Ozeki: Langmuir, 5(1989), 960.

( 5 ) K. Morishige, K. Kawamura and A. Kose: J. Chem. Phys., 93(1990), 5267.

( 6 ) H. Colbeck, B. H. Blott, D. P. Fraser, R. W. Chantrell and D. Melville: Biophysical Effects of Steady Magnetic Fields, Ed. by G. Maret, N. Boccara and J. Kiepenheuer, Springer-Verlag, London, (1986), 34.

( 7 ) P. G. de Gennes and J. Prost: The Physics of Liquid Crystals, Oxford Science Pub., London, (1993), 220; S. Chandrasekhal: Liquid Crystals, Cambridge University press, London, (1992), Capters 3 and 4.

(8) A. Yamagishi, E. Nagao and M. Date: J. Phys. Soc. Jpn, 53 (1984), 928.

( 9 ) H. Kanoh and K. Kaneko: Chem. Phys. Lett., 237(1995), 329; H. Kanoh and K. Kaneko: J. Phys. Chem., 100(1996), 755.

(10) T. Takaishi: J. Chem. Soc.: Faraday Trans., 93(1997), 1257.

(11) H. Hayashi and S. Nagakura: Bull. Chem. Soc. Jpn., 51 (1978), 2862; Y. Sakaguti, H. Hayashi and S. Nagakura: Bull. Chem. Soc. Jpn., 53(1980), 39.

(12) M. Misono and P. W. Selwood: J. Am. Chem. Soc., 90(1968), 2977; P. W. Selwood: Adv. Catal., 27 (1974), 23.

(13) C. Y. Ng, P. W. Tiedemann, B. H. Mahan and Y. T. Lee: J. Chem. Phys., 66(1977), 3985; Ph. Brechignac, S. De Benedictis, N. Halberstadt, B. J. Whitacker and S. Avrillier: J. Chem. Phys., 83(1985), 2064. 